\title{
Douglas-fir climate sensitivity at two contrasting sites along the southern limit of the European planting range
}

\author{
Cristiano Castaldi ${ }^{1} \cdot$ Maurizio Marchi $^{1}$. \\ Giorgio Vacchiano $^{2} \cdot$ Piermaria Corona $^{1}$
}

Received: 21 March 2019 / Accepted: 10 June 2019 / Published online: 3 October 2019

(C) The Author(s) 2019

\begin{abstract}
Douglas-fir (Pseudotsuga menziesii (Mirb.) Franco) is an important exotic tree species that was planted across a large part of Europe during the last century. In both experimental trials and conventional forest plantations, the trees grow at a high rate and produce high-quality timber. The present study investigated climate-growth relationships of Douglas-fir at two Italian sites that contrast in climate: a Mediterranean area in southern Italy (Mercurella site) and a cooler, moister site in the northern Apennines without summer aridity (Acquerino). The relationship between tree-ring chronologies and monthly climatic variables was evaluated by a moving average and correlation analysis. Results showed that the minimum temperature in February and in March play a key role for Douglas-fir at both sites, with a positive effect on growth. At the northern site, it is also highly sensitive to late summer temperatures (negative correlation) and spring-summer precipitation (positive correlation). Growth rates in southern latitudes were high even in Europe and in the Mediterranean environment, with low sensitivity to climatic fluctuation. On the basis of our results,
\end{abstract}

Project funding: The work was supported by the RGV-FAO Project funded by the Italian Ministery of Agricultural, Food and Forestry Policies.

The online version is available at http://www.springerlink.com.

Corresponding editor: Tao Xu.

Maurizio Marchi

maurizio.marchi85@gmail.com;

maurizio.marchi@crea.gov.it

1 CREA - Research Centre for Forestry and Wood, Viale S. Margherita 80, 52100 Arezzo, Italy

2 Università degli Studi di Milano, DISAA, Via Celoria 2, 20133 Milan, Italy further common garden experiments should test adaptation and the interaction between genetics and environment of second- or third-generation seeds from old stands across Europe such as done by the old International Union of Forest Research Organizations (IUFRO) or the European Douglasfir Improvement Research Cooperative (EUDIREC) experimentation programmes.

Keywords Pseudotsuga menziesii . Tree ring analysis . Dendroclimatology $\cdot$ Forest plantations $\cdot$ Exotic forest species

\section{Introduction}

Douglas-fir [Pseudotsuga menziesii (Mirb.) Franco] is one of the most promising exotic tree species in Europe, first introduced from North America more than 150 years ago (Isaac-Renton et al. 2014; Schmid et al. 2014) and currently distributed in almost all European countries (Hermann and Lavender 1999). During the first years of experiments, national or local experimental programmes were established in every European country to collect seeds independently from the native range, mainly according to local climate and expert knowledge. Afterward, a broader programme in the second half of the twentieth century was set up. Within the International Union of Forest Research Organizations (IUFRO) in 1969-1970, an experimental network (Eilmann et al. 2013) tested adaptive traits of 180 provenances of Douglas-fir (both coastal and interior) and represents one of the more extensive and standardized experimental trials in Europe for the species. "Pure seed" collected from almost the whole native range was also compared with some "second-generation provenances", i.e. from plantations in the European introductory range that had already reached 
reproductive age. In this case, growth rates were high, sometimes even higher than the original seeds from the United States or Canada (Ducci and Tocci 1987). Provenance trials demonstrated that, under favourable climatic conditions, Douglas-fir grows faster than native conifers, e.g. Scots pine (Pinus sylvestris L.) or European larch (Larix decidua Miller) in forest stands, too (Eilmann and Rigling 2012). The high degree of genetic variability and plasticity of Douglasfir, due to its huge natural range, are the main reasons for its success. Such characteristics allowed European countries to successfully grow this valuable tree from the Mediterranean to continental Europe (Howe et al. 2010; Brus et al. 2012; Eilmann et al. 2013). However, direct comparisons of the growth response of such introduced provenances to contrasting climates have not been carried out so far. Additionally, most of the plantations were made without any recommendation on the genetic material to be used. Hintsteiner et al. (2018) showed that correctly identifying the provenance of old Douglas-fir stands in Europe could be very difficult. In this sense, relating the performance in the native with that in the introduced zones is generally hard.

The growth of Douglas-fir in its native range is positively affected by precipitation, especially between May and September, often referred as its "growing season" (Case and Peterson 2005) and negatively by winter cold spells and snowpack depth (Littell et al. 2008). Sensitivity to growing season temperatures generally shifts from negative to positive with increasing elevation. However, even at the northernmost/highest sites, precipitation limits Douglas-fir radial growth more than temperatures (Griesbauer and Green 2010). Summer drought is also the main limiting factor for the coastal variety viridis and the interior variety glauca in Europe (Vejpustková and Čihák 2019). Exceptional and recurrent drought often stresses $P$. menziesii more than the species that are native to Europe (Thurm et al. 2016), especially in less fertile soils (Sergent et al. 2014). In Europe, this species may be also promoted by warm winters due to active photosynthesis even in winter months (Chen et al. 2010), possibly combined with the benefit of additional water supply after snowmelt, similar to the case for beech and Norway spruce (Schmid et al. 2014). When compared to native European tree species, Douglas-fir has high potential to cope with warmer climates and higher resistance to drought and subsequent faster recovery.

The various empirical and experimental approaches to assess plant response to climate variability and climate change over large geographic areas (Bréda et al. 2006; Chen et al. 2010) include provenance trials or common gardens (Lipow et al. 2003; Rehfeldt et al. 2014), empirical analyses of growth and mortality in permanent forest inventory plots (Stephenson et al. 2014; Poschenrieder et al. 2018; Marchi 2019; Pecchi et al. 2019), remote sensing and detection of net primary productivity (Smith et al. 2008; Fassnacht et al.
2014) and dendrochronological analysis of growth-climate correlations from tree-ring time series (Eilmann and Rigling 2012; Mazza et al. 2018; Avanzi et al. 2019). One of the most relevant and added values of the last type of approach is that long-term climate-growth responses can be analysed and should elucidate species requirements so that predictions by growth simulators can be adjusted, even for Douglasfir trees outside the native predicted range (Castaldi et al. 2017), and that tree responses to long-term climate variations can be predicted. In particular, dendrochronological climate-growth response models may help to evaluate tree response to past climate variations and to forecast future ecosystem responses to climate change, especially when analysing the same species under different climatic conditions (Härdtle et al. 2014; Corona 2016). If a species shows local growth acclimation, i.e. it responds differently when grown in different climates (Case and Peterson 2005), provenances with a higher tolerance of warm, dry conditions may play an important role in climate change adaptation, because they would probably acclimate well when grown in northern latitudes or higher elevations that are about to experience a warming climate trend (Hampe and Petit 2005; Benito Garzón et al. 2019). Knowledge of available genotypes and information on the genetic structure of forest tree systems (i.e. within-population genetic diversity) is fundamental to coping with a changing climate and understanding long-term adaptation processes to build reliable statistical models and future projections (Piotti et al. 2017; Marchi and Ducci 2018; Benito Garzón et al. 2019).

The aim of this paper is thus to analyse the strength and spatiotemporal stability of the relationship between radial growth of Douglas-fir and main climatic drivers in the Mediterranean environment. To this end, we analysed the growthclimate response of Douglas-fir at two plantation sites in Italy with contrasting climate regimes and discuss the results by means of a dendrochronological analysis.

\section{Materials and methods}

\section{Study sites}

Two sites in Italy were selected where Douglas-fir was extensively tested by the IUFRO and the European Douglas-fir Improvement Research Cooperative (EUDIREC) programmes and by the national/independent experimentation since 1922 (Castaldi et al. 2017): Acquerino in the northern Apennines $\left(44^{\circ} 0^{\prime} 38.97^{\prime \prime} \mathrm{N}, 11^{\circ} 0^{\prime} 25.47^{\prime \prime} \mathrm{E}\right)$ and Mercurella in the southern Apennines ( $\left.39^{\circ} 20^{\prime} 11.55^{\prime \prime} \mathrm{N}, 16^{\circ} 4^{\prime} 49.42^{\prime \prime} \mathrm{E}\right)$ (Fig. 1). Both sites are characterized by pure plantations of Douglas-fir established around the 1940s, with similar elevation (900 and $835 \mathrm{~m}$ a.s.l. respectively). A small amount of information is available on the genotype of the planting 


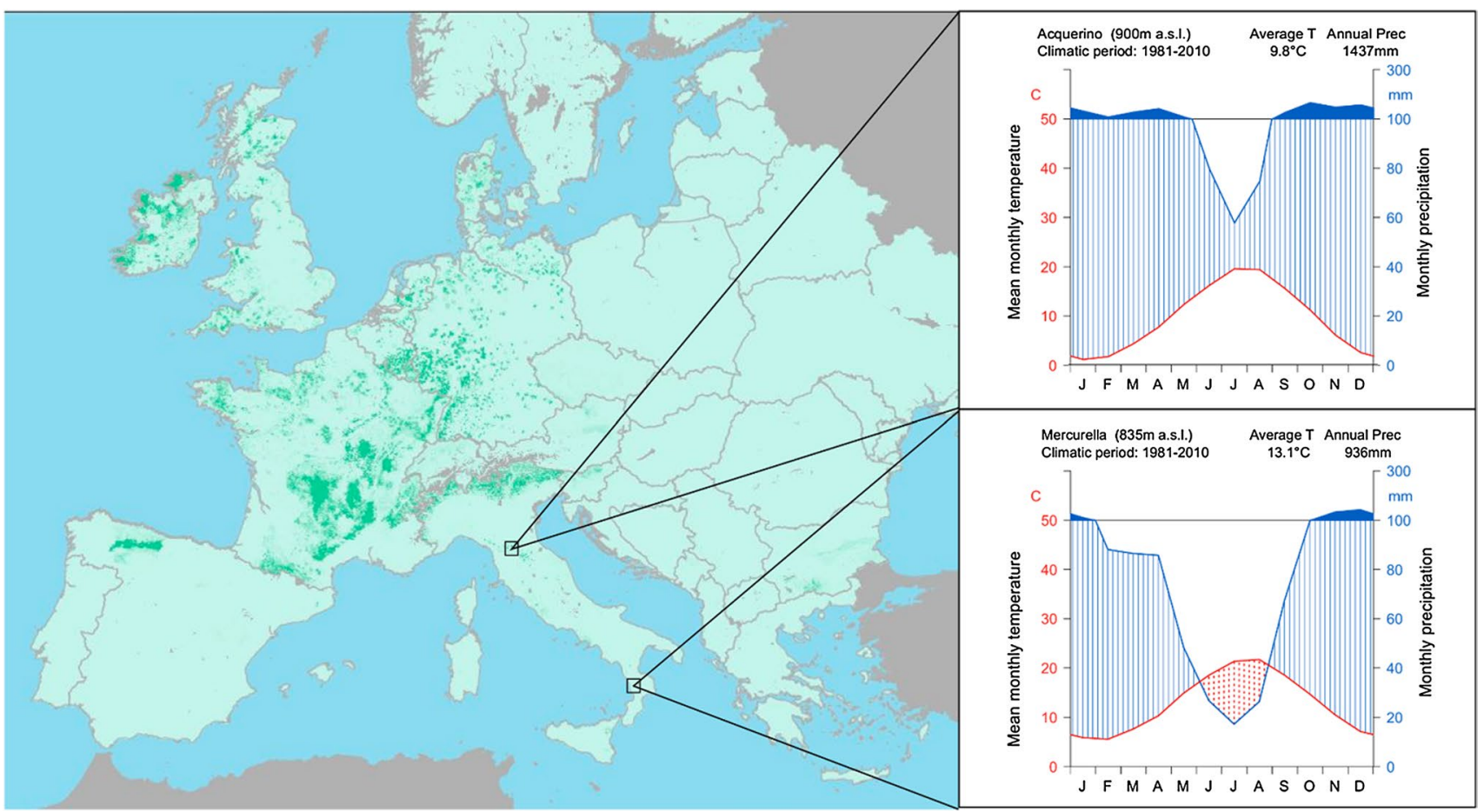

Fig. 1 Location of sampled stands and distribution of Douglasfir in Europe (dark green areas based on Brus et al. 2012). Average monthly climate (1981-2010) diagrams for each study sites are shown on the right. Red line: mean temperature; blue line: precipitation (blue, striped areas: wet periods; red, dotted area: dry period) materials, but according to the literature and information from the archives, both stands were started from 3-year-old seedlings grown in the nursery in Vallombrosa from "Italian" seeds collected from mature trees of unknown origin (probably from Washington, Oregon or California, United States) around the year 1930 (Avolio and Bernardini 2000).

The two sites are characterized by mild climate with average summer mean temperature of $20{ }^{\circ} \mathrm{C}$ (average monthly temperature in June, July and August) and close to the temperature known to be the (so-called) ecological optimum for Douglas-fir growth in the native range (Wang et al. 2012). According to the soil database of Italy (Costantini et al. 2014), the area of Acquerino is mainly characterized by Cambisols (Dystric and Calcaric), Mercurella by Haplic Umbrisols. Different climatic regimes characterize the two sites due to a different latitude and distance from the Mediterranean Sea. The southernmost site (Mercurella) has a warmer and drier climate, with a mean annual temperature of $13.1^{\circ} \mathrm{C}$ and annual precipitation of $936 \mathrm{~mm}$. The northern site (Acquerino) is cooler (mean annual temperature $=9.8{ }^{\circ} \mathrm{C}$ ) and wetter (mean annual precipitation $=1437 \mathrm{~mm}$ ). According to Metzger et al. (2013), Acquerino and Mercurella sites fall within the J (cool temperate and moist) and $\mathrm{K}$ (warm temperate and mesic) bioclimatic belts, respectively. These two sites do not represent the full range of climatic conditions throughout the native range of Douglas-fir in the Pacific Northwest of the United States. However, the northern site has a substantially longer humid period during winter and spring, while the southern one is subject to aridity for the three summer months. In our hypothesis, such differences should be sufficient to highlight differences in local acclimation (Aitken et al. 2008).

No significant disturbance (e.g. windstorms or pests) has been documented for either the sites since planting. The two sites also have similar tree density (Table 1), suggesting a similar silvicultural history (i.e. no thinning was recorded in the last decades at either site). However, although soil samples were not tested, the effect of diverging site fertility was evident: stand top height at Acquerino was 18\% higher than at Mercurella (Table 1).

Table 1 Stand characteristics at the two study sites in Italy

\begin{tabular}{lll}
\hline Characteristic & Acquerino & Mercurella \\
\hline Elevation (m a.s.l.) & 900 & 835 \\
Distance from the sea $(\mathrm{km})$ & 63.8 & 3.4 \\
Trees $\left(\mathrm{ha}^{-1}\right)$ & 247 & 294 \\
Basal area $\left(\mathrm{m}^{2} \mathrm{ha}^{-1}\right)$ & 111.8 & 90.4 \\
Mean DBH $(\mathrm{cm})$ & 75.9 & 62.5 \\
Stand top height $(\mathrm{m})$ & 43.5 & 36.9 \\
\hline
\end{tabular}




\section{Sampling method and tree-ring series preparation}

To obtain comparable data, we designed the sample size according to the sites' characteristics. Indeed, while Mercurella is a pure experimental forest plot approximately 1 ha wide, the Acquerino plantation covers about 30 ha. For this reason, the same number of dominant trees (20) was sampled within each site. First, 20 points were randomly selected across each site. Then the dominant Douglas-fir tree nearest each point was cored twice on the cross-slope side, with an angle of $90^{\circ}$ between cores, at $130 \mathrm{~cm}$ stem height. Cores were fixed on a wooden support to be transported to the laboratory, prepared and measured with $0.01 \mathrm{~mm}$ precision using the tree-ring measuring station LINTAB 6 (RINNTECH, Heidelberg, Germany). Tree-ring series were cross-dated using TSAP-WIN software (RINNTECH), and an average single ring-width series was obtained for each sampled tree. Finally, a site mean chronology was obtained averaging all the single-tree series (20 samples). Each cored tree was also measured for diameter at breast height (DBH) and total height.

After statistical cross-dating, each tree ring series was standardized separately by a double detrending procedure to isolate the climatic signal: a negative exponential curve was first applied to remove age trends, then a spline function (50\% cut-off and 10 years) was fitted to emphasize higher frequency inter-annual climatic variance (Yamaguchi et al. 1991; Biondi and Qeadan 2008; Marchi et al. 2015; Mazza et al. 2018). Autoregressive modelling was performed on each detrended ring-width series to check for the existence of significant $(p<0.05)$ first-order temporal autocorrelation. Residual series were finally averaged using a bi-weight robust mean to obtain mean site chronologies, upon which all subsequent analyses were based. The quality of the sampling procedure was checked by analysing the expressed population signal (EPS), a measure of how well the mean chronology represents the sampled population.

\section{Analysis of climate-growth relationships}

As meteorological stations nearest to the study sites did not provide continuous and consistent data for an ecological study (Ferrara et al. 2017), monthly precipitation and temperatures (maximum and minimum) from 1901 to current time were obtained from the Climate Explorer (http://clime xp.knmi.nl) portal (Trouet and Van Oldenborgh 2013) for the $1 \times 1^{\circ}$ cell where each site was located. The 3 -month standardized precipitation and evaporation index (SPEI) was also calculated for each site, using the SPEI package (Maca and Pech 2016) for R statistical language (R Foundation for Statistical Computing, Vienna, Austria). Because minimum and monthly temperatures were highly correlated at both sites (Pearson's $r=0.982$ and 0.993 , respectively, at
Acquerino and Mercurella), only the maximum was used in subsequent analyses. The same was not evident for SPEI for which Pearson's correlation coefficient was lower than 0.6.

The influence of climate on tree-ring growth was investigated using mean correlation functions (CF) and moving correlation functions (MCF). While the first method is used to evaluate the most influential climatic drivers during the whole life-span of the trees, the second is computed on a moving window with a smaller width to assess the change in growth response through time (Biondi and Waikul 2004; Marchi et al. 2015). A 30-year moving window was applied here, which satisfied the conditions whereby the sample size is less than $80 \%$ of all available years and more than twice the number of predictors (Biondi and Waikul 2004). Maximum temperature, total precipitation and SPEI were computed at a monthly resolution, from May of the previous year $(t-1)$ to September of the year of growth $(t)$, so as to include the autumn and winter before ring formation. Significant Pearson's correlations between mean site chronologies and climate variables were detected using the 95th percentile range method without bootstrap resampling. The R packages dplR (Bunn et al. 2012) and treeclim (Zang and Biondi 2015) were used to manage and analyse tree-ring series. Concerning MCF, a 1-year period was used, starting from October of the previous year $(t-1)$ to September of the year of growth $(t)$.

\section{Results}

The individuals selected at the two sites were on average 68 and 70 years old (two oldest: 78 and 76 years). The average diameter of cored trees was 69 (Acquerino) and $73 \mathrm{~cm}$ (Mercurella). Mean sensitivity was around 0.125 at both sites with a mean ring width between 4 and $5 \mathrm{~mm} \mathrm{yr}^{-1}$ (Table 2). Of all individual raw tree-ring series (Fig. 2), 60\% at Acquerino and $85 \%$ at Mercurella could be fitted by a negative exponential curve; for the others, a linear decreasing or horizontal fit was used in the first detrending.

As evidenced by Fig. 2, a negative pointer year (defined as an extremely narrow tree-ring width with growth reduction exceeding $40 \%$ compared with the average value in the previous 4 years) was clearly evident for the Mercurella site in 1981-1982. Moreover, we found a very wide ring in 1980 followed by two very narrow rings in 1981 and 1982. These were connected to an exceptionally long growing season in 1980 and a heavy frost event in autumn. This event seriously damaged tree needles, and 2 years were needed for the trees to regenerate their crown.

Over the analysed period, the residual ring-width site chronologies (Fig. 3) had a mean inter-series correlation (RBAR) of 0.42 and 0.36 , negligible first-order autocorrelation, and an EPS much higher than 0.85, the value generally 
Table 2 Statistical parameters of mean tree-ring width chronologies for the two study sites in Italy

\begin{tabular}{lll}
\hline Parameter & Acquerino & Mercurella \\
\hline Mean DBH, cored trees (cm) & $69.4 \pm 5.1$ & $73.1 \pm 4.7$ \\
Length of site chronology (years) & 78 & 76 \\
Mean sampling depth (number of cores) & $14.9 \pm 4.5$ & $16.3 \pm 2.2$ \\
Mean sensitivity & $0.121 \pm 0.03$ & $0.127 \pm 0.04$ \\
Mean ring width (mm) & $4.969 \pm 1.66$ & $4.031 \pm 1.83$ \\
Expressed population signal (EPS) & 0.926 & 0.918 \\
Mean interseries correlation (RBAR) & $0.418 \pm 0.11$ & $0.365 \pm 0.12$ \\
Signal-to-noise ratio & 12.452 & 10.544 \\
First-order autocorrelation after indexing (chrono) & -0.144 & 0.179 \\
\hline
\end{tabular}
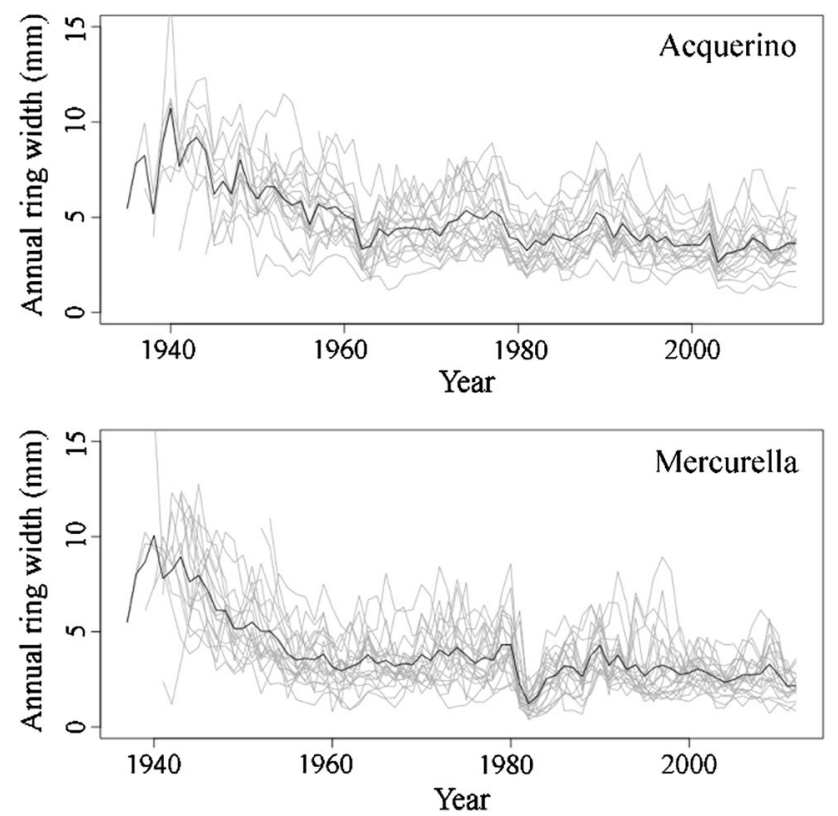

Fig. 2 Raw individual chronologies (grey lines) and mean chronology (black line) at the Acquerino (above) and Mercurella (below) sites

accepted as the minimum threshold to detect valid climatic correlations and indicating a common macro-environmental influence on growth (Wigley et al. 1984).

Both sites exhibited a significant climatic trend during the second half of the last century ( $p$ value for the regression slope $<0.05)$ as a drying trend at the northern site of Acquerino, and a warming trend at Mercurella (Fig. 4). Many significant correlations between growth and climate variables were found by CF (Fig. 5). At Acquerino, maximum temperature was significant in July of the year before growth, February (positive correlation) and during the midand late summer of the growth year (July, August, September: negative correlation). Precipitation showed a negative correlation with growth in October and November of the previous year $(t-1)$, and positive in May and July of the current year. Summer SPEI (July-October) had a positive effect

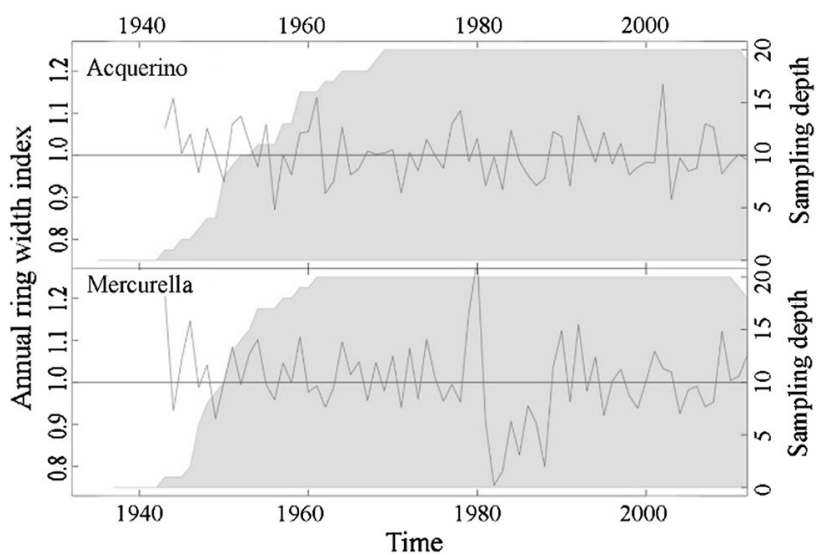

Fig. 3 Detrended mean chronology for each study site. The grey area of each figure represents the number of cores (sampling depth) used to calculate the mean values ranging between 2 (10\% of the samples) and 20 (100\% of the samples). Lower sampling depth values on the left are due to shorter cores that were either broken or collected from younger trees

on growth with a lag of 1 year and a negative effect (July) of growth in the current year. Fewer months were detected as significant at Mercurella. Ring width was significantly negatively correlated with maximum temperatures in October $(t-1)$ and July. A positive correlation arose only with temperatures in the winter of the year of growth $t$ (February and March). Precipitation was only significantly negatively correlated with growth in December $(t-1)$, while a negative effect on growth was detected for SPEI on June $(t-1)$.

The MCF analysis highlighted several periods with significant correlation between ring width and climate, but not all the correlations were stable over time. At Acquerino, spring and summer temperatures were rarely significant, except February and also March during 1958-1988, which were highlighted by a stable positive correlation. The average maximum temperature in September became relevant during the last decades for growth of the current year, and in 1955-1991 for growth of the following year as a possible prolonging of the vegetative season. In the first part of the study period, maximum temperature of the previous May 


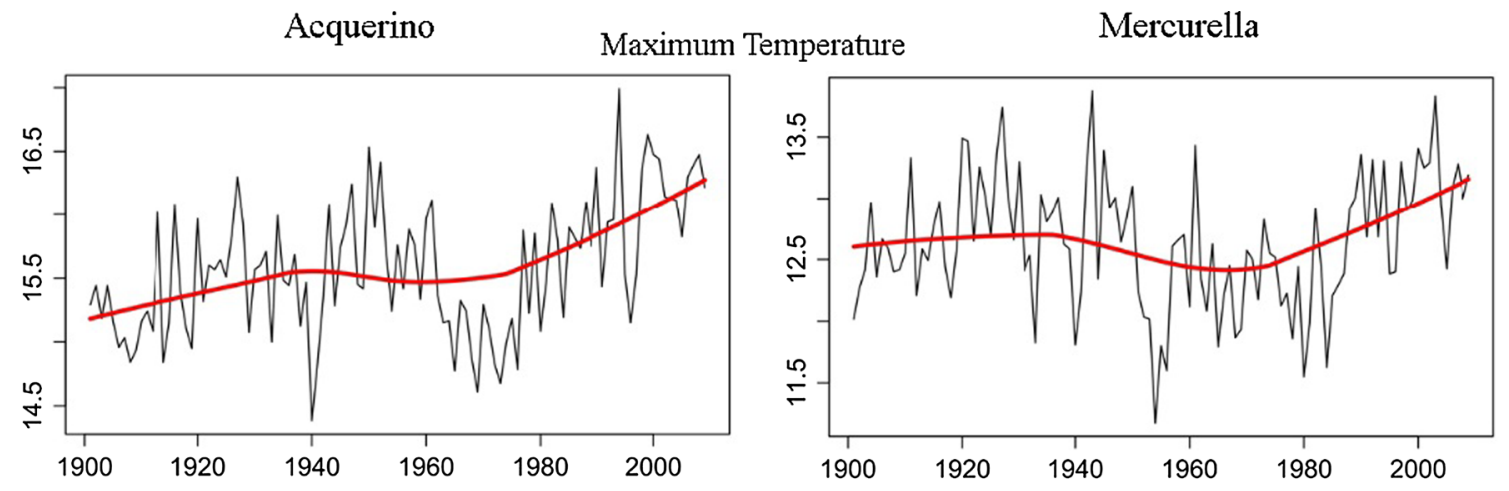

Precipitation
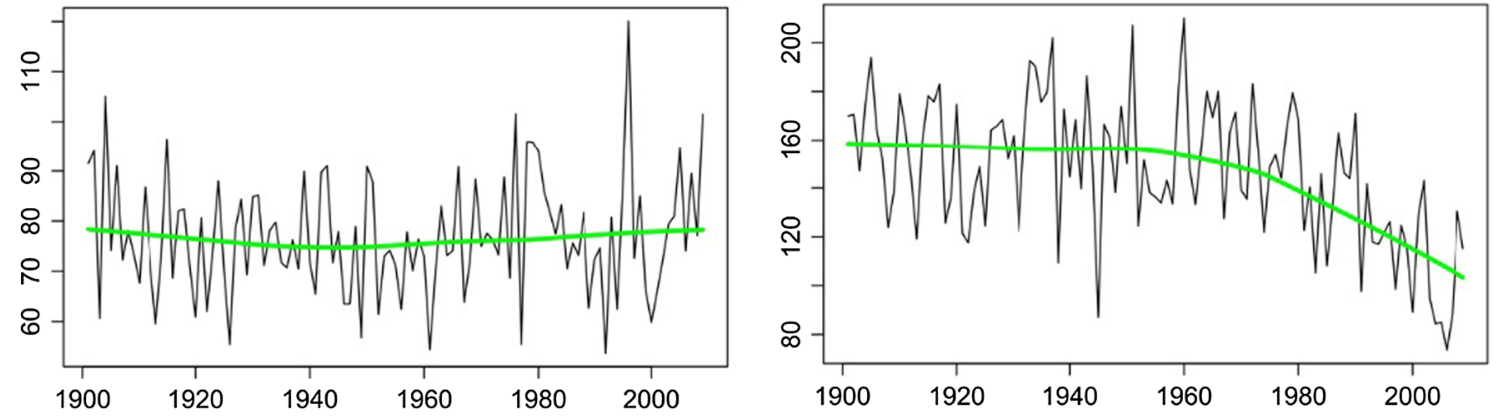

SPEI
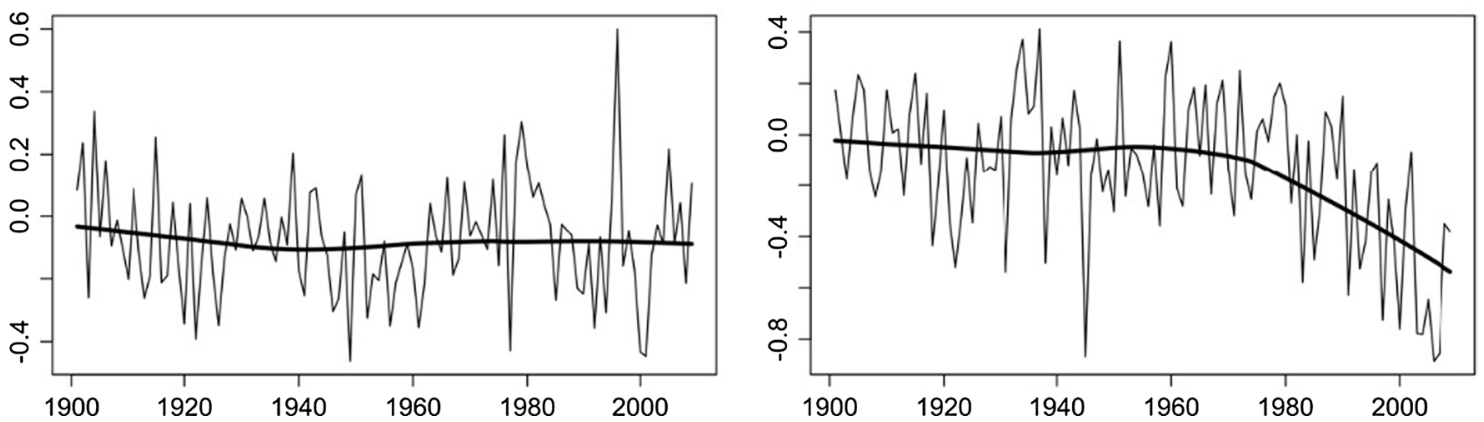

Fig. 4 Raw climatic time series at Acquerino (left) and Mercurella (right) collected from 1901 to 2010. The thinner, smoothed continuous line represents the periodic (5-year) mean

also had a positive influence on tree ring width (Fig. 6). Correlations with SPEI and water availability were also unstable, with a positive influence of previous year precipitation shifting from September to June, and of current year from July to May. Summer drought (measured by SPEI) had generally a negative effect on growth, but was significant only in recent years. On the contrary, a significantly positive effect of water availability the previous summer was detected for the first part of the study period. At Mercurella, MCF evidenced similar relationships with growth, i.e. a stable positive influence of February/March maximum temperature, a negative influence of December $(t-1)$ precipitation and positive influence of September $(t-1)$ precipitation, and a generally positive effect of water availability (positive SPEI) in the year before growth. An additional relevant effect was the negative influence of July maximum temperature on current year growth, which has been significant since 1960 . Possible impacts on growth trends might also be addressed for a water supply reserve in soil, since the two stands are growing on different soil types: Haplich Umbrisols (more humid) at the Mercurella site, Cambisols at the Acquerino site.

\section{Discussion}

The Mediterranean basin represents the southern edge of the Douglas-fir introduction range in Europe and here, with a Mediterranean (Mercurella) or a more continental (Acquerino) climate, the late winter (February and March) 
Acquerino
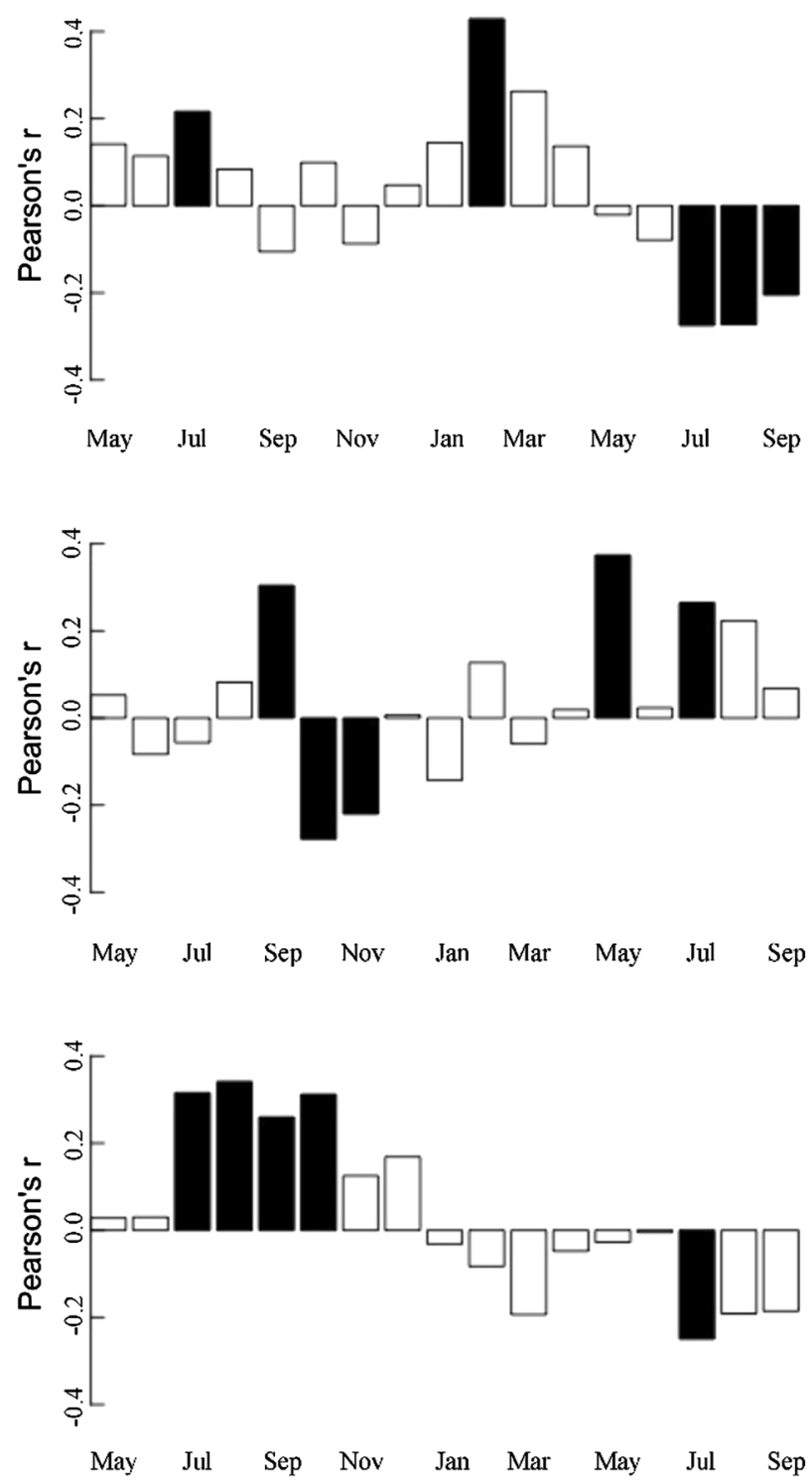

Mercurella
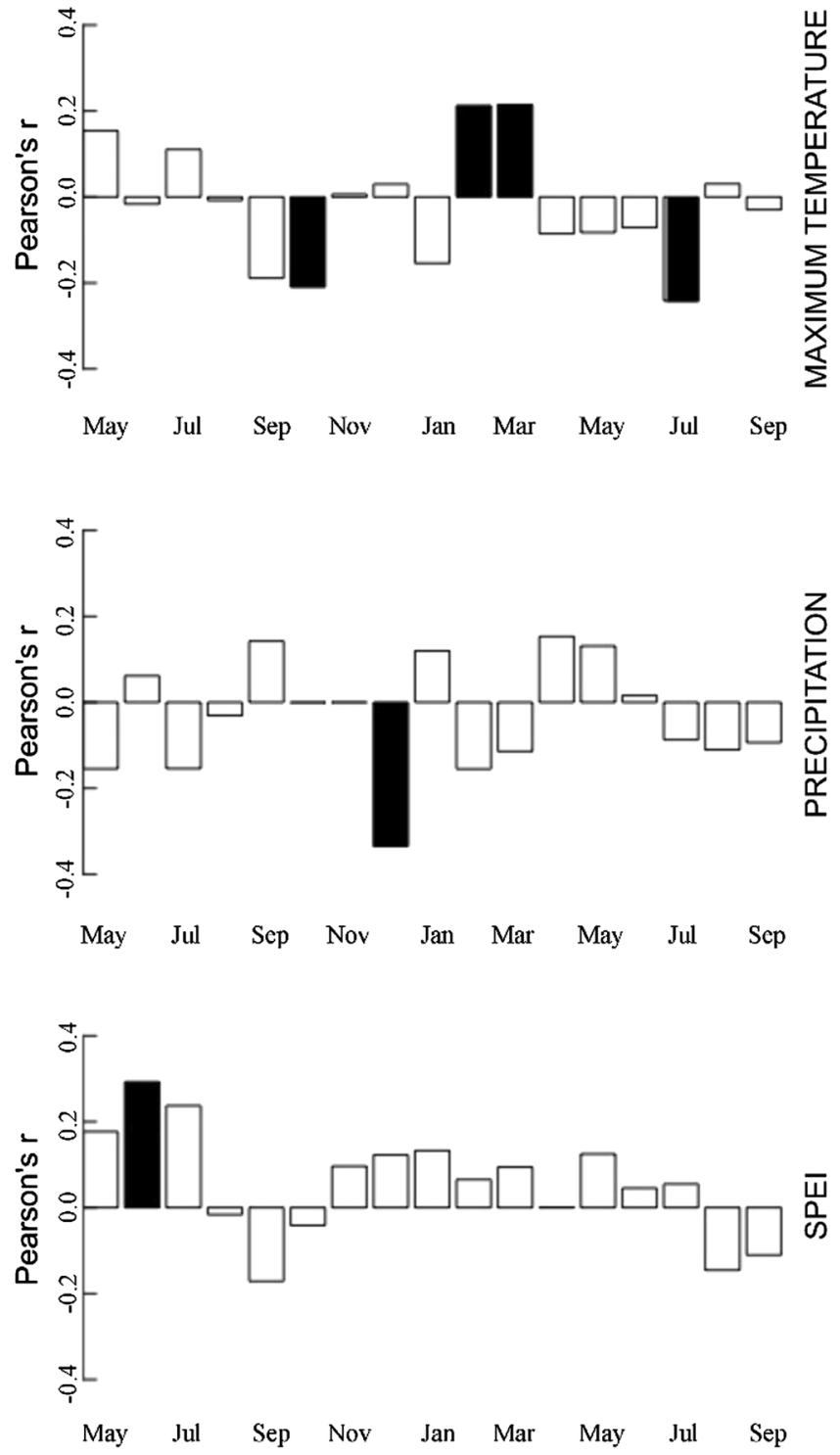

Fig. 5 Correlation functions (CF) between detrended average chronology (ring width) and climatic variables at each site (significant correlations, $p<0.05$, are marked by black bars). The months of the growing year (i.e. the year of the ring-width formation) are reported on the $\mathrm{x}$-axis

is recognised as a key season for Douglas-fir growth. On the basis of the obtained empirical evidence, our findings may explain the successful introduction of such a valuable exotic forest tree species even at the southern limits of Europe. According to our analysis, climate sensitivity of Douglasfir was almost half of what has been previously reported in Italy for Abies alba Mill. or Fagus sylvatica L. (Mazza et al. 2014; Rita et al. 2014), i.e. tree species representing the potential natural vegetation at our study sites. This aspect might suggest a relatively low interaction between climate and tree species, i.e. growth trends uncorrelated with the local climate. The positive correlation between growth and February-March temperatures, which also has been reported in other studies in Europe (e.g. Thurm et al. 2016), highlights that some cambial activity is possible even in winter, an important adaptive trait of many conifer species (Gričar et al. 2015). The absence of frost events during winter might favour species growth in the vegetative season. For instance, the negative pointer year we found around 1980s was mainly due to intense foliar damage during the winter, which probably limited photosynthesis in the first part of the following growing season. Then, summer temperature in the year of 


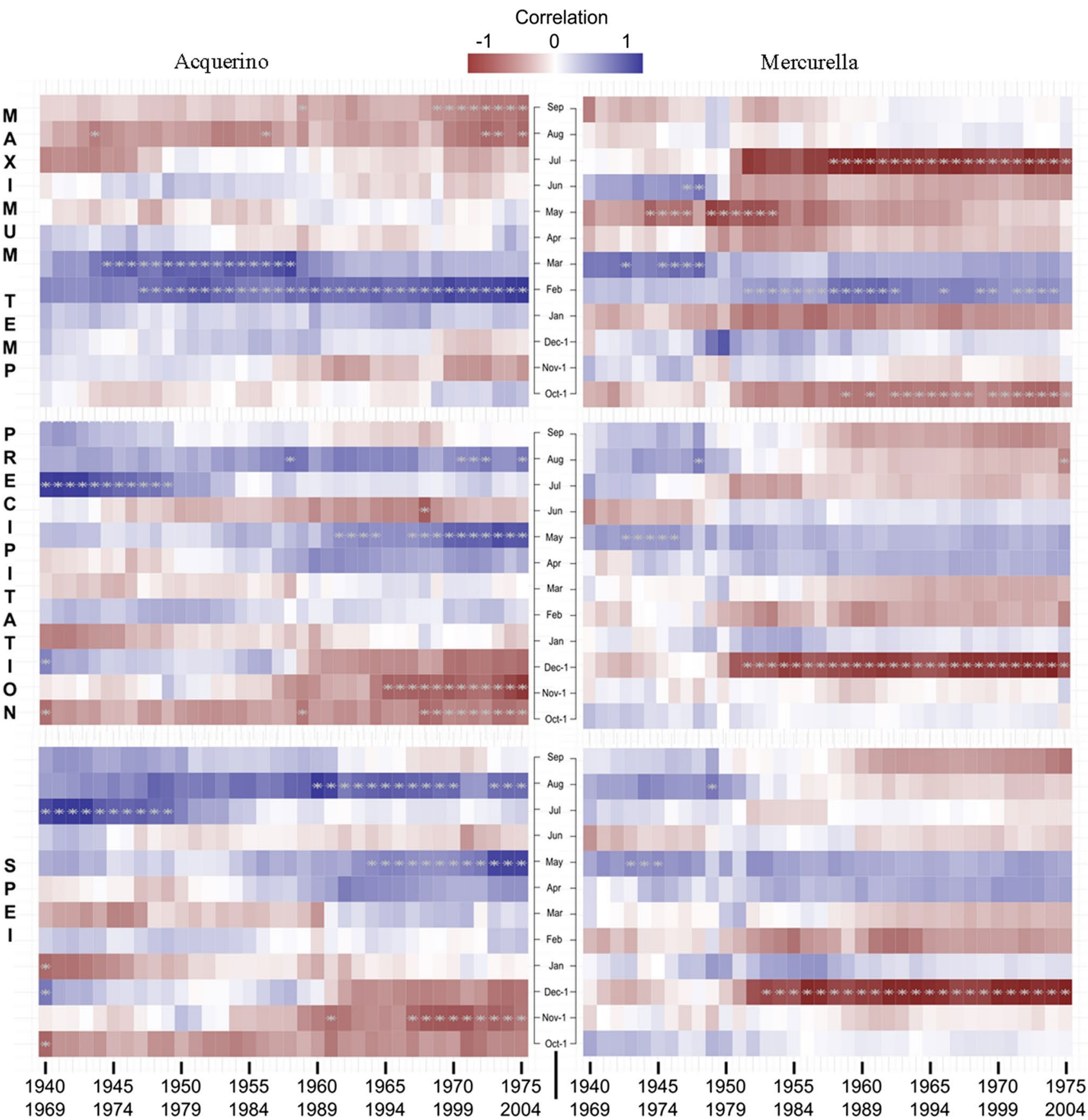

Fig. 6 Moving correlation functions (MCF) between detrended average chronology and climatic variables at each site. Each square represents a correlation value calculated on a 30 -year moving window (significant correlations, $p<0.05$, are marked by white stars)

growth was found to be a limiting factor in both climates considered here; the fact that summer temperature in the previous year instead have a positive influence might be related to faster organic matter turnover and higher resource availability for growth in the following year.

Summer precipitation was recognized as an influencing factor only at the northern location (Acquerino), suggesting local acclimation and also a different temporal regulation of photosynthesis and physiological activity for the southernmost provenance. On the other hand, high precipitation in autumn preceding growth has a negative effect on productivity at both sites, which might seem counter intuitive, but can be explained by a complementary effect between rain and snow. Rain gauges are generally not able to measure both snow and rain; measurements of low rainfall in late autumn and early winter months might "hide" snowfall (relatively frequent at both sites), which is beneficial to next year's growth via increased water availability in the soil after 
snowmelt (Littell et al. 2008). Whether this effect is due to a different genetic structure or to phenotypic plasticity is unknown.

The current-year growing conditions are mainly able to influence latewood growth, whereas earlywood growth is influenced by conditions in the previous and current year (Eilmann and Rigling 2012; Watson and Luckman 2002). In this case and regarding water balance, previous year drought was found to strongly limit growth (probably via an influence on earlywood formation) only at Acquerino, which usually lacks aridity in the summer and has more fertile soil (stand top height at age 70, Table 1). Only 1 month of significant correlation between tree ring width and SPEI has been detected at Mercurella. Recent studies have found Douglas-fir to be vulnerable to exceptional and recurrent drought episodes only on low fertility sites (Sergent et al. 2014), which is the opposite of our findings. However, Mercurella is both drier and hotter than Acquerino and closer to the seaside. In this particular environment, trees might have deal with low water availability and moisture deficit by local acclimation. Such an effect may be stronger than what is implied by soil characteristics. Another possibility might consider this skill as already included in the genotype of the trees and not expressed in other zones (Mathys et al. 2014). This research question should be addressed with suitable molecular techniques. Indeed, the genetic provenance of old Douglas-fir stands in Europe is rarely known and was only recently addressed by means of dedicate sampling procedures and nuclear markers (Hintsteiner et al. 2018). In this framework, it remains unknown whether instead the smaller top height at the southern site is a result of some resistance (i.e. productivity tradeoff of the southern provenance). To answer this question, common garden experiments with such provenance could be used to evaluate the productive performance of this seed source under different climate regimes. Actually, the growth response to climatic conditions in the previous year and winter based on tree-ring width time series measured at an annual time step is supposed to be maintained. This aspect might open new research scenarios for other studies where second-stage seed sources from such old Douglas-fir stands might represent a valuable potential for forest management in Italy. Testing provenance materials and monitoring the growth response of rear-edge populations in warm and dry climates is fundamental for adaptive forest management (Provan and Maggs 2012): under such a perspective, this study could represent an opportunity to derive useful insight on this exotic species in Europe. Climate is challenging for plant growth across the whole continent, in the warm-temperate zone due to summer aridity with increasing temperatures and in wetter areas that are undergoing significant drying trends. Under this scenario, acclimated old populations of Douglas-fir with high growth plasticity and tolerance to drought (Isaac-Renton et al. 2014;
Boiffin et al. 2017) may be seen as having good potential for timber supply in Europe (Rais et al. 2014; Sergent et al. 2014). The role of active forest management may be relevant in this end, since stand structure can have a significant influence on the mitigation of water stress, also in the case of Douglas-fir (Rebetez et al. 2006; Mazza et al. 2018).

The MCF analysis showed a quite complicated framework, where just few correlations were stable and dominant across time. This aspect was not surprising given the nature of the relationship: an exotic species introduced in a new environment. The analysis detected that the strength and significance of most correlations with Douglas-fir growth against temperature, precipitation and SPEI shifted from months in the year before growth to those in the year when growth occurs. At Acquerino, late summer temperature became significantly limiting only after the year 1970 (and after 1960 at Mercurella). However, this aspect should not be addressed as a possible adaptation of the species. The negative correlations of growth with summer temperature in the recent decades suggest that temperatures have increased and are now at or above the temperature optimum for growth, i.e. around $20{ }^{\circ} \mathrm{C}$ (Briffa et al. 2001). No consistent sign could be found for any divergence-like weakening of tree responses to temperature in recent decades (Wigley et al. 1984; Briffa et al. 1998). The most important month for winter temperature also shifted from March to February at Acquerino and for summer precipitation from July to May as a possible consequence of the anticipation of growing season onset and precipitation reduction induced by climate change. Also, at Mercurella, drought in the previous year maintained its importance throughout the study, which may again reflect the interaction between climate and soil in determining tree growth (i.e. a higher water availability may compensate for the limitation of a poor soil by increasing the resources available to the tree in the following year).

\section{Conclusions}

After almost 100 years in Europe, Douglas-fir has demonstrated commercially relevant potential for timber production across Europe. Known as a relatively drought-tolerant species, fair acclimation capacity is now acknowledged for this valuable tree species when grown in warm, dry climates (southern provenances). It is relevant to highlight that the Mercurella stand here examined represents the southernmost plantation at the southern limit of European planting range of Douglas-fir. However, the differences in potential maximum productivity between southern and northern Mediterranean provenances have to be further assessed. Common garden experiments should be planned that will properly test adaptation of the second- or third-generation seed generated by old Douglas-fir stands across Europe. Then a comparative 
study on adaptation of this species in both zones, in Europe and the Pacific Northwest in the United States, collecting seeds from both and to test them with a novel field-trial network to be established in both areas might reveal unexpected scenarios also for tree breeding. In our opinion, further experimental work should be welcomed such as the IUFRO 1960s experimentation and the EUDIREC (Grant agreement ID: FAIR950909) Project.

Acknowledgements Besides of the financial support from the RGVFAO Project, Cristiano Castaldi has received the support by University of Tuscia (Italy) as Ph.D. student. The authors thank an anonymous reviewer for helpful suggestions on an earlier draft of this paper.

Open Access This article is distributed under the terms of the Creative Commons Attribution 4.0 International License (http://creativeco mmons.org/licenses/by/4.0/), which permits unrestricted use, distribution, and reproduction in any medium, provided you give appropriate credit to the original author(s) and the source, provide a link to the Creative Commons license, and indicate if changes were made.

\section{References}

Aitken SN, Yeaman S, Holliday JA, Wang T, Curtis-McLane S (2008) Adaptation, migration or extirpation: climate change outcomes for tree populations. Evol Appl 1:95-111. https://doi.org/10.111 1/j.1752-4571.2007.00013.x

Avanzi C, Piermattei A, Piotti A, Büntgen U, Heer K, Opgenoorth L, Spanu I, Urbinati C, Vendramin GG, Leonardi S (2019) Disentangling the effects of spatial proximity and genetic similarity on individual growth performances in Norway spruce natural populations. Sci Total Environ 650:493-504. https://doi.org/10.1016/j. scitotenv.2018.08.348

Avolio S, Bernardini V (2000) La parcella sperimentale N 412 di douglasia verde di Pavari nella Catena Costiera calabra a settant'anni dall'impianto [The experimental plot N 412 of green Douglas fir in the coastal mountain chain after seventy years from its establishment]. Ann Silvic Res 31:119-136

Benito Garzón M, Robson TM, Hampe A (2019) $\Delta$ TraitSDM: species distribution models that account for local adaptation and phenotypic plasticity. New Phytol. https://doi.org/10.1111/nph.15716

Biondi F, Qeadan F (2008) A theory-driven approach to tree-ring standardization: defining the biological trend from expected basal area increment. Tree Ring Res 64:81-96. https://doi. org/10.3959/2008-6.1

Biondi F, Waikul K (2004) DENDROCLIM2002: a C++ program for statistical calibration of climate signals in tree-ring chronologies. Comput Geosci 30:303-311. https://doi.org/10.1016/j.cageo 2003.11.004

Boiffin J, Badeau V, Bréda N (2017) Species distribution models may misdirect assisted migration: insights from the introduction of Douglas-fir to Europe. Ecol Appl 27:446-457. https://doi. org/10.1002/eap1448

Bréda N, Huc R, Granier A, Dreyer E (2006) Temperate forest trees and stands under severe drought: a review of ecophysiological responses, adaptation processes and long-term consequences. Ann For Sci 63:625-644. https://doi.org/10.1051/forest

Briffa KR, Schweingruber FH, Jones PD, Osborn TJ, Shiyatov SG, Vaganov EA (1998) Reduced sensitivity of recent tree-growth to temperature at high northern latitudes. Nature 391:678-682. https ://doi.org/10.1038/35596

Briffa KR, Osborn TJ, Schweingruber FH, Harris IC, Jones PD, Shiyatov SG, Vaganov EA (2001) Low-frequency temperature variations from a northern tree ring density network. J Geophys Res 106:2929. https://doi.org/10.1029/2000JD900617

Brus DJ, Hengeveld GM, Walvoort DJJ, Goedhart PW, Heidema AH, Nabuurs GJ, Gunia K (2012) Statistical mapping of tree species over Europe. Eur J For Res 131:145-157. https://doi.org/10.1007/ s10342-011-0513-5

Bunn AG, Korpela M, Biondi F, Campelo F, Mérian P, Qeadan F, Zang C (2012) dplR: Dendrochronology program library in $R$. R Package Version 1.5.4., http://CRAN.R-project.org/packa ge $=$ dplR. Accessed 3 Sept 2018

Case MJ, Peterson DL (2005) Fine-scale variability in growth-climate relationships of Douglas-fir, North Cascade Range, Washington. Can J For Res 35:2743-2755. https://doi.org/10.1139/x05-191

Castaldi C, Vacchiano G, Marchi M, Corona P (2017) Projecting nonnative Douglas fir plantations in southern Europe with the forest vegetation simulator. For Sci 63:101-110. https://doi.org/10.5849/ forsci.16-048

Chen PY, Welsh C, Hamann A (2010) Geographic variation in growth response of Douglas-fir to interannual climate variability and projected climate change. Glob Change Biol 16:3374-3385. https:// doi.org/10.1111/j1365-2486201002166x

Corona $\mathrm{P}$ (2016) Consolidating new paradigms in large-scale monitoring and assessment of forest ecosystems. Environ Res 144:8-14. https://doi.org/10.1016/jenvres201510017

Costantini E, Barbetti R, Fantappiè M, L'Abate G, Lorenzetti R, Napoli R, Marchetti A, Rivieccio R (2014) The soil map of Italy a hierarchy of geodatabases, from soil regions to sub-systems. In: GlobalSoilMap basis of the global spatial soil information system, pp 109-112 https://doi.org/10.1201/b16500-23

Ducci F, Tocci A (1987) Primi risultati della sperimentazione IUFRO 1969-70 su Pseudotsuga menziesii (Mirb) Franco nell'appennino centro-settentrionale [First results of IUFRO/1969-70 experimentation on Pseudotsuga menziesii (Mirb) Franco in Northern and Central Apennines]. Ann dell'Istituto Sper per la Selvic $18: 215-289$

Eilmann B, Rigling A (2012) Tree-growth analyses to estimate tree species' drought tolerance. Tree Physiol 32:178-187. https://doi. org/10.1093/treephys/tps004

Eilmann B, de Vries SMG, den Ouden J, Mohren GMJ, Sauren P, SassKlaassen U (2013) Origin matters! Difference in drought tolerance and productivity of coastal Douglas-fir (Pseudotsuga menziesii (Mirb)) provenances. For Ecol Manag 302:133-143. https://doi. org/10.1016/jforeco201303031

Fassnacht FE, Hartig F, Latifi H, Berger C, Hernández J, Corvalán P, Koch B (2014) Importance of sample size, data type and prediction method for remote sensing-based estimations of aboveground forest biomass. Remote Sens Environ 154:102-114. https://doi. org/10.1016/jrse201407028

Ferrara C, Marchi M, Fares S, Salvati L (2017) Sampling strategies for high quality time-series of climatic variables in forest resource assessment. iForest 10:739-745. https://doi.org/10.3832/ifor2 427-010

Gričar J, Prislan P, de Luis M, Gryc V, Hacurová J, Vavrčík H, Čufar $\mathrm{K}$ (2015) Plasticity in variation of xylem and phloem cell characteristics of Norway spruce under different local conditions. Front Plant Sci 6:1-14. https://doi.org/10.3389/fpls201500730

Griesbauer HP, Green DS (2010) Assessing the climatic sensitivity of Douglas-fir at its northern range margins in British Columbia, Canada. Trees 24:375-389. https://doi.org/10.1007/s0046 8-009-0407-z 
Hampe A, Petit RJ (2005) Conserving biodiversity under climate change: the rear edge matters. Ecol Lett 8:461-467. https://doi. org/10.1111/j1461-0248200500739x

Härdtle W, Niemeyer T, Fichtner A, Li Y, Ries C, Schuldt A, Walmsley D, von Oheimb G (2014) Climate imprints on tree-ring $\delta 15 \mathrm{~N}$ signatures of sessile oak (Quercus petraea Liebl) on soils with contrasting water availability. Ecol Indic 45:45-50. https://doi. org/10.1016/jecolind201403015

Hermann RK, Lavender DP (1999) Douglas-fir planted forests. New For 17:53-70. https://doi.org/10.1023/A:1006581028080

Hintsteiner WJ, van Loo M, Neophytou C, Schueler S, Hasenauer H (2018) The geographic origin of old Douglas-fir stands growing in Central Europe. Eur J For Res 0:1-15. https://doi.org/10.1007/ s10342-018-1115-2

Howe GT, Jayawickrama K, Cherry M, Johnson GR, Wheeler NC (2010) Breeding Douglas-fir. Plant breeding reviews. Wiley, Oxford, pp 245-353. https://doi.org/10.1002/9780470650349ch6

Isaac-Renton MG, Roberts DR, Hamann A, Spiecker H (2014) Douglas-fir plantations in Europe: a retrospective test of assisted migration to address climate change. Glob Change Biol 20:2607-2617. https://doi.org/10.1111/gcb12604

Lipow SR, Johnson GR, St Clair JB, Jayawickrama KJ (2003) The role of tree improvement programs for Ex situ gene conservation of coastal Douglas-fir in the Pacific Northwest. For Genet 10:111-120

Littell JS, Peterson DL, Tjoelker M (2008) Douglas-fir growth in mountain ecosystems: water limits tree growth from stand to region. Ecol Monogr 78:349-368. https://doi.org/10.1890/07-07121

Maca P, Pech P (2016) Forecasting SPEI and SPI drought indices using the integrated artificial neural networks. Comput Intell Neurosci $1-17$

Marchi M (2019) Nonlinear versus linearised model on stand density model fitting and stand density index calculation: analysis of coefficients estimation via simulation. J For Res 1:2-3. https://doi. org/10.1007/s11676-019-00967-0

Marchi M, Ducci F (2018) Some refinements on species distribution models using tree-level national forest inventories for supporting forest management and marginal forest population detection. iForest 11:291-299. https://doi.org/10.3832/ifor2441-011

Marchi M, Castaldi C, Merlini P, Nocentini S, Ducci F (2015) Stand structure and influence of climate on growth trends of a Marginal forest population of Pinus nigra spp nigra. Ann Silvic Res 39:100-110. https://doi.org/10.12899/asr-1066

Mathys A, Coops NC, Waring RH (2014) Soil water availability effects on the distribution of 20 tree species in western North America. For Ecol Manag 313:144-152

Mazza G, Gallucci V, Manetti MC, Urbinati C (2014) climate-growth relationships of silver fir (Abies alba Mill) in marginal populations of Central Italy. Dendrochronologia 32:181-190. https://doi. org/10.1016/jdendro201404004

Mazza G, Sarris D, Chiavetta U, Ferrara RM, Rana G (2018) An intra-stand approach to identify intra-annual growth responses to climate in Pinus nigra subsp. laricio Poiret trees from southern Italy. For Ecol Manag 425:9-20. https://doi.org/10.1016/jfore co201805029

Metzger MJ, Bunce RG, Jongman RH, Sayre R, Trabucco A, Zomer R (2013) High-resolution bioclimate map of the world. Global Ecol Biogeogr 22:630-638. https://doi.org/10.1111/geb.12022

Pecchi M, Marchi M, Giannetti F, Bernetti I, Bindi M, Moriondo M, Maselli F, Fibbi L, Corona P, Travaglini D, Chirici G (2019) Reviewing climatic traits for the main forest tree species in Italy. iForest 12:173-180. https://doi.org/10.3832/ifor2835-012

Piotti A, Leonarduzzi C, Postolache D, Bagnoli F, Spanu I, Brousseau L, Urbinati C, Leonardi S, Vendramin GG, Urfm UR (2017) Unexpected scenarios from Mediterranean refugial areas: disentangling complex demographic dynamics along the Apennine distribution of silver fir. J Biogeogr 44:1547-1558. https://doi. org/10.1111/jbi.13011

Poschenrieder W, Biber P, Pretzsch H (2018) An inventory-based regeneration biomass model to initialize landscape scale simulation scenarios. Forests 9:212. https://doi.org/10.3390/f9040212

Provan J, Maggs CA (2012) Unique genetic variation at a species' rear edge is under threat from global climate change. Proc Biol Sci 279:39-47. https://doi.org/10.1098/rspb20110536

Rais A, van de Kuilen JWG, Pretzsch H (2014) Growth reaction patterns of tree height, diameter, and volume of Douglas-fir (Pseudotsuga menziesii [Mirb] Franco) under acute drought stress in Southern Germany. Eur J For Res 133:1043-1056. https://doi. org/10.1007/s10342-014-0821-7

Rebetez M, Mayer H, Dupont O (2006) Heat and drought 2003 in Europe: a climate synthesis. Ann For Sci 63:569-577. https:// doi.org/10.1051/forest

Rehfeldt GE, Jaquish BC, López-upton J, Sáenz-romero C, St JB, Leites LP, Joyce DG (2014) Comparative genetic responses to climate for the varieties of Pinus ponderosa and Pseudotsuga menziesii: realized climate niches. For Ecol Manag 324:138-146. https://doi.org/10.1016/jforeco201402041

Rita A, Gentilesca T, Ripullone F, Todaro L, Borghetti M (2014) Differential climate-growth relationships in Abies alba Mill and Fagus sylvatica L in Mediterranean mountain forests. Dendrochronologia 32:220-229. https://doi.org/10.1016/jdendro201 404001

Schmid M, Pautasso M, Holdenrieder O (2014) Ecological consequences of Douglas fir (Pseudotsuga menziesii) cultivation in Europe. Eur J For Res 133:13-29. https://doi.org/10.1007/s1034 2-013-0745-7

Sergent AS, Rozenberg P, Bréda N (2014) Douglas-fir is vulnerable to exceptional and recurrent drought episodes and recovers less well on less fertile sites. Ann For Sci 71:697-708. https://doi. org/10.1007/s13595-012-0220-5

Smith B, Knorr W, Widlowski JL, Pinty B, Gobron N (2008) Combining remote sensing data with process modelling to monitor boreal conifer forest carbon balances. For Ecol Manag 255:3985-3994. https://doi.org/10.1016/jforeco200803056

Stephenson NL, Das AJ, Condit R, Russo SE, Baker PJ, Beckman NG, Coomes DA, Lines ER, Morris WK, Rüger N, Álvarez E, Blundo C, Bunyavejchewin S, Chuyong G, Davies SJ, Duque Á, Ewango CN, Flores O, Franklin JF, Grau HR, Hao Z, Harmon ME, Hubbell SP, Kenfack D, Lin Y, Makana JR, Malizia A, Malizia LR, Pabst RJ, Pongpattananurak N, Su SH, Sun IF, Tan S, Thomas D, Van Mantgem PJ, Wang X, Wiser SK, Zavala MA (2014) Rate of tree carbon accumulation increases continuously with tree size. Nature 507:90-93. https://doi.org/10.1038/nature12914

Thurm EA, Uhl E, Pretzsch H (2016) Mixture reduces climate sensitivity of Douglas-fir stem growth. For Ecol Manag 376:205-220. https://doi.org/10.1016/jforeco201606020

Trouet V, Van Oldenborgh GJ (2013) KNMI climate explorer: a webbased research tool for high-resolution paleoclimatology. Tree Ring Res 69:3-13. https://doi.org/10.3959/1536-1098-6913

Vejpustková M, Čihák T (2019) Climate response of douglas fir reveals recently increased sensitivity to drought stress in central Europe. Forests 10:97. https://doi.org/10.3390/f10020097

Wang TL, Campbell EM, O’Neill GA, Aitken SN (2012) Projecting future distributions of ecosystem climate niches: uncertainties and management applications. For Ecol Manage 279:128-140. https ://doi.org/10.1016/jforeco201205034

Watson E, Luckman BH (2002) The dendroclimatic signal in Douglasfir and ponderosa pine tree-ring chronologies from the southern Canadian Cordillera. Can J For Res 32:1858-1874. https://doi. org/10.1139/x02-096

Wigley TML, Briffa KR, Jones PD (1984) On the average value of correlated time series, with applications in dendroclimatology 
and hydrometeorology. J Clim Appl Meteorol. https://doi. org/10.1175/1520-0450(1984)023\%3c0201:OTAVOC\%3e20CO;2

Yamaguchi DK, Cook ER, Kairiukstis LA (1991) Methods of dendrochronology, applications in the environmental sciences. Arct Alp Res 23:120. https://doi.org/10.2307/1551446

Zang C, Biondi F (2015) Treeclim: an R package for the numerical calibration of proxy-climate relationships. Ecography (Cop) 38:431-436. https://doi.org/10.1111/ecog01335
Publisher's Note Springer Nature remains neutral with regard to jurisdictional claims in published maps and institutional affiliations. 